\title{
Reaksi Pasar Atas Momentum Hari Raya Idul Fitri Tahun 2019
}

\author{
Gede Rama Wirya Nanda ${ }^{1}$ \\ Fakultas Ekonomi dan Bisnis \\ Universitas Udayana, Indonesia \\ Email: gdwiryananda@gmail.com
}

\author{
Made Gede Wirakusuma ${ }^{2}$ \\ Fakultas Ekonomi dan Bisnis \\ Universitas Udayana, Indonesia
}

\begin{abstract}
ABSTRAK
Penelitian ini bertujuan untuk mengetahui adanya reaksi pasar atas momentum hari raya Idul Fitri tahun 2019. Penelitian ini merupakan eventstudy dengan periode pengamatan selama 14 hari. Penelitian dilakukan pada perusahaan yang tergolong Jakarta Islamic Index (JII) pada tahun 2019. Populasi dalam penelitianini adalah 30 perusahaan. Metode penentuan sampel yang digunakan adalah metode sampel jenuh. Sampel yang diperoleh sebanyak 30 perusahaan. Reaksi pasar atas momentum hari raya Idul Fitri tahun 2019 diukur menggunakan abnormal return dan trading volume activity. Teknik analisis data yang digunakan yaitu uji one-sample t-test. Hasil pengujian menunjukkan bahwa terdapat reaksi pasar saat hari raya Idul Fitri tahun 2019 yang ditunjukkan dengan abnormal return dan trading volume activity yang signifikan disekitar tanggal peristiwa. Hal ini menunjukkan hari raya Idul Fitri tahun 2019 menimbulkan reaksi pasar dikarenakan terdapat kandungan informasi pada peristiwa tersebut.
\end{abstract}

Kata Kunci: Event Study; Abnormal Return; Trading Volume Activity.

Market Reaction on the Momentum of Idul Fitri in 2019

\begin{abstract}
This study aims to determine the market reaction to the momentum of Idul Fitri in 2019. This research is an event study with an observation period of 14 days. The study was conducted at companies classified as the Jakarta Islamic Index (JII) in 2019. The population in this study was 30 companies. The sampling method used is the saturated sample method. Samples obtained were 30 companies. Market reaction to the momentum of Idul Fitri in 2019 is measured using abnormal returns and trading volume activity. The data analysis technique used is the one-sample t-test. The test results show that there is a market reaction during the Idul Fitri in 2019 which is indicated by a significant abnormal return and trading volume activity around the event date. This shows that Idul Fitri in 2019 caused a market reaction because of there was an information content of the event.
\end{abstract}

Keywords: Event Study; Abnormal Return; Trading Volume Activity.

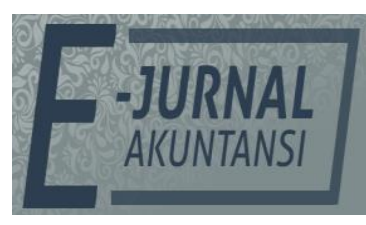

E-JA

e-Jurnal Akuntansi e-ISSN 2302-8556

Vol. 30 No. 5

Denpasar, Mei 2020

Hal. 1247-1257

Artikel Masuk: 14 Januari 2020

Tanggal Diterima: 5 Maret 2020 


\section{PENDAHULUAN}

Pasar modal merupakan alternatif investasi yang dapat memberikan keuntungan dengan memperhitungkan risiko yang telah diperhitungkan (Meylita, 2015). Semakin penting peran pasar modal bagi suatu negara maka semakin sensitif pasar modal tersebut terhadap berbagai peristiwa yang memiliki kandungan informasi (Suryawijaya \& Setiawan, 1998). Pasar modal yang terus berkembang dan memiliki kinerja yang stabil dapat mempengaruhi daya saing perekonomian suatu negara serta mempengaruhi minat investor baik dalam negeri maupun luar negeri untuk berinvestasi di suatu negara (Levine \& Zervos, 1998). Peristiwa yang mengandung informasi akan sangat berdampak pada reaksi pasar dan akan tampak pada perubahan harga saham dan volume saham yang diperdagangkan. Reaksi yang timbul pada pasar perdagangan saham merupakan respon investor dalam melakukan kegiatan investasi. Apabila informasi baru semakin cepat diserap dan tercermin pada harga sekuritas, maka dapat dikatakan semakin efisien pasar modal tersebut.

Sesuai dengan konsep dasar efisiensi dan kondisi ideal pasar efisien, maka pasar modal yang efisien secara informasional dapat diklasifikasikan menjadi tiga bentuk pasar efisien (Fama, 1970) yaitu efisiensi pasar bentuk lemah (weak form), efisiensi pasar bentuk semikuat (semi-strong form), dan efisiensi pasar bentuk kuat (strong form). Pasar efisien dalam bentuk lemah berarti semua informasi di masa lalu akan tercermin dalam harga yang terbentuk saat ini. Pasar efisien dalam bentuk setengah kuat merupakan bentuk efisiensi pasar yang lebih komprehensif karena dalam bentuk ini harga saham tidak hanya dipengaruhi oleh data pasar, tetapi juga dipengaruhi oleh semua informasi yang dipublikasikan. Pasar efisien dalam bentuk kuat yaitu semua informasi baik yang terpublikasi maupun tidak dipublikasikan, sudah tercermin dalam harga sekuritas saat ini.

Investor dalam melakukan keputusan investasinya akan sangat memperhatikan informasi-informasi yang berasal dari berbagai peristiwa, baik itu peristiwa ekonomi maupun non ekonomi. Peristiwa ekonomi dapat berupa inflasi, kurs valas, corporate action. Sedangkan peristiwa non ekonomi meliputi seperti isu-isu yang terjadi seputaran HAM, lingkungan sosial, maupun peristiwa politik lainnya (Permana, 2013). Peristiwa non ekonomi terkadang bisa menjadi pemicu adanya reaksi pasar modal (Jatmiko et al., 2014). Hal lain yang penting bagi pasar modal yaitu peran informasi. Investor dalam melakukan keputusan investasinya akan sangat memperhatikan kandungan informasi yang dapat berasal dari beragam peristiwa (Chang et al., 2016)

Perubahan harga dapat dilihat dari adanya abnormal return sedangkan volume transaksi dapat dilihat dari trading volume activity. Abnormal return merupakan selisih antara return yang sebenarnya dengan return yang diharapkan (Hartono, 2015). Return adalah hasil yang didapatkan dari investasi. Menurut Hartono (2015 : 263), return dapat berupa return realisasi yang sudah terjadi atau return ekspektasi yang belum terjadi, tetapi yang diharapkan akan terjadi dimasa mendatang.

Menurut Andri (2013) trading volume activity merupakan alat ukur untuk melihat reaksi pasar modal melalui pergerakan volume perdagangan pada saat pasar modal tersebut diteliti. Cerminan dari tingkah laku investor dapat dilihat 
dari perkembangan volume perdagangan saham yang mencerminkan kekuatan antara penawaran dan permintaan .

Menurut Analis Reliance Sekuritas Indonesia, memang setiap tahunnya setiap kali hari raya Idul Fitri pasar modal terasa lesu. Banyak pelaku pasar yang justru melakukan aksi jual. Hal ini secara logis dikarenakan investor merealisasikan keuntungan untuk Tabungan Hari Raya (THR). Dalam hal ini investor lokal akan memilih untuk mencairkan portofolio sahamnya dalam rangka memenuhi kebutuhan hari raya. Selain itu libur panjang hari raya Idul Fitri juga mendorong investor untuk menarik dulu dananya dari pasar modal untuk sementara waktu. (finance.detik.com).

Adapun berikut gambar pergerakan harga saham yang terdaftar di JII pada tahun 2018:

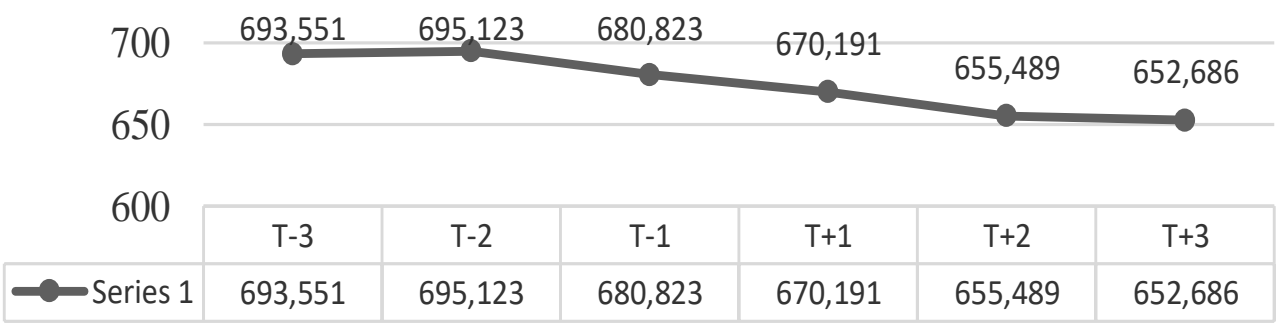

Gambar 1. Gambar Index Saham JII Sebelum dan Sesudah Hari Raya Idul Fitri 2018

Sumber: Data Penelitian, 2019

Berdasarkan Gambar 1. dapat dilihat bahwa pergerakan index JII mengalami fluktuasi. Pada tiga hari sebelum (T-3) libur hari raya Idul Fitri 2018, index JII berada pada level 693,551. Pada (T-2) atau dua hari sebelum libur hari raya Idul Fitri 2018, Index JII meningkat ke level 695,123. Namun, pada (T-1) atau satu hari sebelum libur hari raya Idul Fitri 2018, index JII menurun cukup drastis ke level 680,823 dan terus mengalami penurunan pada $(\mathrm{T}+1)$ hingga $(\mathrm{T}+3)$ setelah libur hari raya Idul Fitri 2018, dimana pada (T+1), Index JII berada di level 670,191. Pada (T+2) Index JII berada di level 655, 489, dan pada (T+3) terus turun ke level 652, 686. Pergerakan index JII yang mengalami penurunan cukup tajam pada libur hari raya idul fitri 2018 menyebabkan penelitian mengenai reaksi pasar atas momentum hari raya idul fitri ini menarik untuk diteliti lebih lanjut.

Penelitian mengenai reaksi pasar atas hari raya Idul Fitri sebelumnya telah banyak dilakukan. Diantaranya adalah penelitian yang dilakukan oleh Utomo \& Herlambang (2015) menyatakan abnormal return tidak berpengaruh signifikan pada saat sebelum dan sesudah hari raya Idul Fitri tahun 2011-2013. Hal ini sejalan dengan penelitian yang dilakukan oleh Marini (2016), Anggraini (2017), dan Chrisnanti (2015) yang mendapatkan hasil bahwa tidak ada perbedaan ratarata abnormal return baik sebelum dan sesudah adanya peristiwa hari raya Idul Fitri. Namun penelitian yang dilakukan oleh Hasanuddin (2015) menemukan hasil yang berbeda, dimana pada penelitian ini terdapat perbedaan abnormal return sebelum dan sesudah peristiwa hari raya Idul Fitri pada saham-saham yang terdaftar di JII maupun non-JII periode 2009-2013. Hal ini sejalan dengan penelitian yang dilakukan oleh Pujiadi \& Indriani (2017) yang menunjukkan terdapat perbedaan abnormal return sebelum dan sesudah hari libur Idul Fitri. 
Penelitian mengenai perbedaan trading volume activity pada libur hari raya Idul Fitri juga telah banyak dilakukan. Diantaranya adalah penelitian yang dilakukan oleh Marini (2016) mendapatkan hasil tidak ada perbedaan trading volume activity baik sebelum ataupun sesudah libur hari raya Idul Fitri tahun 2011-2015. Hal ini sejalan dengan penelitian yang dilakukan oleh Anggraini (2017) yang menyatakan bahwa tidak ada perbedaan trading volume activity sebelum dan sesudah libur hari raya Idul Fitri tahun 2014-2016. Hasil tersebut berbeda dengan penelitian yang dilakukan oleh Setiasri \& Rinofah (2017) yang menemukan hasil trading volume activity berpengaruh signifikan pada saat sebelum dan sesudah hari raya Idul Fitri. Hal ini sejalan dengan penelitian yang dilakukan oleh Suhadak \& Hidayat (2016), Utomo \& Herlambang (2015) mendapatkan hasil terdapat perbedaan trading volume activity di bulan Ramadhan.

Abnormal return atau excess return merupakan kelebihan dari return yang sesungg uhnya terjadi terhadap return normal (Hartono, 2016:667). Return normal merupakan return ekspektasian (return yang diharapkan oleh investor). Dengan demikian return tak normal (Abnormal Return) adalah selisih antara return sesungguhnya yang terjadi dengan return ekspektasian. Menurut teori efisiensi pasar, bila pengumuman mengandung informasi maka pasar akan bereaksi. Reaksi pasar dapat dilihat dari adanya Abnormal Return saham yang diterima oleh investor. Begitu juga sebaliknya, apabila pengumuman tidak mengandung informasi maka pasar tidak akan bereaksi sehingga tidak terdapat Abnormal Return.

Penelitian yang dilakukan oleh Hasanuddin (2015) menyatakan bahwa terdapat perbedaan abnormal return sebelum dan sesudah peristiwa hari raya Idul Fitri pada saham-saham yang terdaftar di JII maupun non-JII periode 2009-2013. Hal ini sejalan dengan penelitian yang dilakukan oleh Pujiadi dan Indriani (2017) yang menunjukkan terdapat perbedaan abnormal return sebelum dan sesudah hari libur Idul Fitri. Berdasarkan uraian tersebut, maka rumusan hipotesis yang dapat diajukan dalam penelitian ini:

$\mathrm{H}_{1}$ : Terdapat Abnormal Return pada saat hari raya Idul Fitri tahun 2019.

Adanya reaksi pasar modal terhadap suatu informasi dapat dilihat dengan trading volume activity selain melihat abnormal return. Trading volume activity adalah suatu indikator yang dapat digunakan untuk melihat reaksi pasar modal terhadap informasi melalui parameter pergerakan aktivitas volume perdagangan saham di pasar modal (Suryawijaya \& Setiawan, 1998). Perhitungan trading volume activity adalah dengan membandingkan jumlah saham perusahaan yang diperdagangkan dengan keseluruhan jumlah saham beredar perusahaan selama periode penelitian.

Menurut Sutrisno (2000) volume perdagangan saham merupakan suatu instrumen yang dapat digunakan untuk melihat reaksi pasar modal terhadap informasi yang diperdagangkan di pasar. Saham yang aktif diperdagangkan merupakan indikasi aktivitas volume perdagangan saham yang besar. Hal ini dapat menurunkan tingkat bid-ask spread, dimana pedagang tidak akan lama menyimpan saham tersebut sebelum diperdagangkan.

Penelitian yang dilakukan oleh Setiasri \& Rinofah (2017) menemukan hasil Trading Volume Activity berpengaruh signifikan pada saat sebelum dan sesudah 
hari raya Idul Fitri. Hal ini sejalan dengan penelitian yang dilakukan oleh Suhadak \& Hidayat (2016), Utomo \& Herlambang (2015) mendapatkan hasil terdapat perbedaan trading volume activity di bulan Ramadhan.

$\mathrm{H}_{2}$ : Terdapat Trading Volume Activity pada saat hari raya Idul Fitri tahun 2019.

Return saham adalah pendapatan yang dinyatakan dalam persentase dari modal awal investasi. Pendapatan investasi dalam saham meliputi keuntungan jual beli saham, jika untung disebut capital gain sedangkan jika rugi disebut capital loss. Return saham mengacu pada kerugian atau keuntungan investasi yang sensitif terhadap ekspektasi fundamental dan teknis di pasar (Frankel dan Lee, 1998). Return pada ekuitas saham biasa dihitung dengan membagi laba bersih dikurangi dividen preferen oleh ekuitas pemilik dikurangi nilai nominal dari saham preferen yang beredar. Investor juga mendapatkan dividen setiap tahunnya antara lain dividen interim yang dibayarkan selama tahun berjalan dan dividen final yang dibayarkan setelah tutup tahun buku. Return saham menunjukkan pola sistematis pada waktu-waktu tertentu dalam sehari, minggu atau bulan.. Return saham dapat berupa return realisasian yang sudah terjadi atau return ekspektasian yang belum terjadi tetapi yang diharapkan akan terjadi di masa mendatang (Harvey et al., 2016).

Menurut (Hartono, 2015) suatu peristiwa yang mengandung informasi akan memberikan abnormal return kepada investor dan sebaliknya peristiwa yang tidak mengandung informasi tidak akan memberikan abnormal return kepada investor. Abnormal return adalah selisih antara return sesungguhnya yang terjadi dengan return ekspektasi. Apabila return yang didapatkan lebih besar dari return yang diharapkan disebut selisih return yang positif, sedangkan apabila return yang didapatkan lebih kecil dari return yang diharapkan disebut selisih return negatif. Nguyen (2017) menjelaskan abnormal return harian dihitung sebagai selisih return harian dan expected return.

Event study menggambarkan sebuah teknik riset yang memungkinkan peneliti untuk menilai dan menganalisis dampak dari suatu peristiwa tertentu terhadap pergerakan harga saham. Event study melibatkan estimasi return normal untuk keamanan dan menghitung arah dan ukuran kelebihan return yang diakibatkan oleh informasi yang tidak diantisipasi (Hall \& Kenjegaliev, 2017). Fungsi event study yaitu untuk menguji kandungan informasi (information content) dari suatu pengumuman atau peristiwa dalam hal ini adalah Idul Fitri tahun 2019 dan dapat juga digunakan untuk menguji efisiensi pasar bentuk setengah kuat. Pengujian event study pada awalnya lebih terfokus pada peristiwa internal perusahaan, seperti stock split (Schatzberg \& Datta, 1992). Event window dalam penelitian ini adalah 14 hari yaitu 7 hari sebelum, dan 7 hari sesudah Idul Fitri tahun 2019. Alasan memilih 7 hari sebelum, 1 hari peristiwa dan 7 hari sesudah Hari Raya Idul Fitri tahun 2019 adalah karena peneliti menilai dengan menggunakan 14 hari merupakan jumlah yang tepat untuk mengetahui respon dari para investor atas kejadian pengumuman suatu peristiwa.

Event study berusaha mendeteksi respon pasar terhadap suatu peristiwa atau pengumuman yang dipublikasikan. Apabila pengumuman ataupun suatu peristiwa mengandung informasi, maka diharapkan pasar akan bereaksi pada saat pengumuman atau peristiwa itu terjadi. Reaksi pasar dapat dilihat dari adanya perubahan harga saham dari sekuritas yang bersangkutan. Reaksi ini 
dapat diukur dengan menggunakan return ataupun dengan abnormal return. Apabila suatu pengumuman atau peristiwa memiliki kandungan informasi, maka hal ini dapat dilihat dari adanya abnormal return dan sebaliknya apabila suatu pengumuman atau peristiwa tidak memiliki kandungan informasi maka tidak akan ada abnormal return.

Salah satu indikator yang dapat digunakan untuk melihat reaksi pasar terhadap suatu peristiwa adalah trading volume activity. Trading volume activity merupakan bagian yang diterima dalam analisis teknikal. Trading volume activity yang tinggi akan mengindikasikan pasar dalam kondisi baik. Harga saham akan lebih murah saat terjadinya pemecahan harga saham yang akan menyebabkan volume perdagangan saham menjadi lebih besar dan akan menarik investor untuk memiliki saham tersebut ataupun dapat menarik minat investor untuk menambah jumlah saham yang diperdagangkan. Meningkatnya volume perdagangan saham merupakan indikasi dari kenaikan aktivitas jual beli yang dilakukan oleh investor. Perkembangan volume perdagangan saham mencerminkan kekuatan antara penawaran dan permintaan yang merupakan cerminan dari tingkah laku investor.

\section{METODE PENELITIAN}

Penelitian ini dilakukan pada perusahaan-perusahaan yang terdaftar di Jakarta Islamic Index (JII) yang terdaftar di Bursa Efek Indonesia (BEI). Data perusahaanperusahaan yang digunakan dalam penelitian ini diperoleh dari www.idx.co.id. Lokasi penelitian dilakukan di Bursa Efek Indonesia karena tersedianya data yang lengkap terkait dengan penelitian yang dilakukan.

Populasi dalam penelitian ini adalah perusahaan yang tergabung indeks Jakarta Islamic Index (JII) periode 2019 yang terdaftar di Bursa Efek Indonesia. Pengambilan sampel berarti mengambil sebagian saja dari populasi untuk menggambarkan populasi secara keseluruhan atau representatif. Sampel pada penelitian ini adalah perusahaan yang terdaftar di Jakarta Islamic Index (JII) periode 2019.

Berdasarkan penelitian ini karena jumlah populasinya tidak lebih besar dari 100 responden, maka penulis mengambil 100\% jumlah populasi yang ada pada indeks Jakarta Islamic Index yaitu sebanyak 30 perusahaan. Dengan demikian penggunaan seluruh populasi tanpa harus menarik sampel penelitian sebagai unit observasi disebut sebagai teknik sensus.

Teknik analisis data yang digunakan dalam penelitian ini adalah one sample $t$-test. Pengujian one sample $t$-test untuk menguji hipotesis pada penelitian ini digunakan untuk menguji terdapat atau tidaknya reaksi pasar yang signifikan saat Hari Raya Idul Fitri tahun 2019 yang dilihat dari abnormal return dan trading volume activity disekitar Hari Raya Idul Fitri tahun 2019. Apabila pengujian memiliki nilai probabilitas $>0,05$ maka $\mathrm{H}_{0}$ diterima dan $\mathrm{H}_{1}$ ditolak sedangkan apabila nilai probabilitas $\leq 0,05$ maka $\mathrm{H}_{0}$ ditolak dan $\mathrm{H}_{1}$ diterima.

\section{HASIL DAN PEMBAHASAN}

Hasil analisis data ini merupakan hasil pengamatan metode event study mengenai reaksi pasar atas momentum hari raya Idul Fitri tahun 2019, dimana hari raya Idul Fitri tahun 2019 jatuh pada tanggal 5 Juni 2019. Periode pengamatan 
menggunakan 14 hari pengamatan, dimana 7 hari sebelum hari raya Idul Fitri tahun 2019, dan 7 hari sesudah hari raya Idul Fitri tahun 2019.

Penelitian ini dilakukan pada perusahaan yang terdaftar dalam indeks Jakarta Islamic Index (JII). Pemilihan indeks JII dikarenakan JII berisikan sahamsaham yang memenuhi kriteria syariah dan memiliki kapitalisasi pasar yang besar serta liquid (Umam, 2012).

Tabel 1. Uji Statistik Deskriptif CAR \& TVA

\begin{tabular}{cccccc}
\hline & $\mathrm{N}$ & Minimum & Maximum & Mean & $\begin{array}{c}\text { Std. } \\
\text { Deviation }\end{array}$ \\
\hline CAR & 30 & $-0,1700$ & 0,2390 & 0,0309 & 0,0812 \\
TVA & 30 & 0,0053 & 0,1689 & 0,0292 & 0,0318 \\
\hline
\end{tabular}

Sumber: Data Penelitian, 2019

Berdasarkan Tabel 1. dapat dilihat bahwa secara statistic Cumulative Abnormal Return (CAR) secara keseluruhan dengan 30 perusahaan yang digunakan selama 14 hari pengamatan, diperoleh nilai minimum sebesar - 0,1700 yang dimiliki oleh PT. Matahari Department Store Tbk. Nilai maksimum CAR sebesar 0,2390 dimiliki oleh PT. Erajaya Swasembada Tbk. Nilai rata-rata CAR sebesar 0,0309, dengan standar deviasi sebesar 0,0812.

Berdasarkan Tabel 1. dapat dilihat bahwa secara statistic Trading Volume Activity (TVA) secara keseluruhan dengan 30 perusahaan yang digunakan selama 14 hari pengamatan, diperoleh nilai minimum sebesar 0,0053 yang dimiliki oleh PT.Unilever Indonesia Tbk. Nilai maksimum TVA sebesar 0,1689 dimiliki oleh PT.Erajaya Swasembada Tbk. Nilai rata-rata TVA sebesar 0,0292, dengan standar deviasi sebesar 0,0318.

Tabel 2. Uji Normalitas CAR \& TVA

\begin{tabular}{lllllll}
\hline & \multicolumn{2}{l}{ Kolmogorov-Smirnov $^{a}$} & \multicolumn{3}{l}{ Shapiro-Wilk } \\
& Statistic & Df & Sig. & Statistic & $d f$ & Sig. \\
\hline CAR & 0,127 & 30 & 0,200 & 0,955 & 30 & 0,234 \\
& & & $*$ & & & \\
TVA & 0,098 & 30 & $*, 200$ & 0,971 & 30 & 0,562
\end{tabular}

Sumber: Data Penelitian, 2019

Berdasarkan Tabel 2. dapat diketahui nilai dari signifikansi Cumulative Abnormal Return (CAR) atas hari raya Idul Fitri tahun 2019 sebesar 0,200 > 0,05 yang berarti bahwa data berdistribusi normal, sehingga dapat diteruskan analisisnya ke dalam statistic parametrik yaitu uji one sample t-test.

Berdasarkan Tabel 2. dapat diketahui nilai dari signifikansi Trading Volume Activity (TVA) atas hari raya Idul Fitri tahun 2019 sebesar 0,200 > 0,05 yang berarti bahwa data berdistribusi normal, sehingga dapat diteruskan analisisnya ke dalam statistic parametrik yaitu uji one sample t-test.

Pengujian hipotesis ini menggunakan uji one sample t-test yang diolah dengan software IBM SPSS Statistic 24. Hasil uji hipotesis dapat dilihat dalam Tabel 3.

Berdasarkan Tabel 3. uji one sample t-test diperoleh nilai t 2,087 dengan nilai probabilitas sebesar $0,046<a(0,05)$, yang berarti bahwa terdapat reaksi pasar atas hari raya Idul Fitri tahun 2019 yang ditunjukan dengan adanya Abnormal Return yang signifikan, yang berarti $\mathrm{H}_{1}$ diterima. 
Tabel 3. Uji One Sample t-test CAR \& TVA

\begin{tabular}{|c|c|c|c|c|c|c|}
\hline \multicolumn{7}{|c|}{ Test Value $=0$} \\
\hline & \multirow[t]{2}{*}{$\mathrm{T}$} & \multirow[t]{2}{*}{ Df } & \multirow{2}{*}{$\begin{array}{l}\text { Sig. } \\
\text { tailed) }\end{array}$} & \multirow{2}{*}{$\begin{array}{l}\text { Mean } \\
\text { Difference }\end{array}$} & \multicolumn{2}{|c|}{ Interval of the Difference } \\
\hline & & & & & Lower & Upper \\
\hline CAR & 2,087 & 29 & 0,046 & 0,0309 & 0,0006 & 0,0613 \\
\hline TVA & 5,027 & 29 & 0,000 & 0,0292 & 0,0173 & 0,0410 \\
\hline
\end{tabular}

Sumber: Data Penelitian, 2019

Berdasarkan Tabel 3. uji one sample t-test diperoleh nilai t 5,027 dengan nilai probabilitas sebesar $0,000<a(0,05)$, yang berarti bahwa terdapat reaksi pasar atas hari raya Idul Fitri tahun 2019 yang ditunjukan dengan adanya Trading Volume Activity yang signifikan, yang berarti $\mathrm{H}_{2}$ diterima.

Hasil pengujian hipotesis pertama $\left(\mathrm{H}_{1}\right)$ melalui uji One Sample T-test memperlihatkan bahwa pada tingkat kepercayaan 95\% nilai Sig. (2-tailed) 0,046 < 0,05, maka dapat dikatakan bahwa $\mathrm{H}_{1}$ diterima. Hal ini mengartikan bahwa terdapat reaksi pasar atas hari raya Idul Fitri tahun 2019 yang ditunjukkan dengan adanya Abnormal Return yang signifikan. Berdasarkan hasil tersebut dapat dikatakan bahwa peristiwa hari raya Idul Fitri tahun 2019 berpengaruh bagi pelaku pasar terhadap kegiatan di pasar modal Indonesia. Informasi yang terkandung dalam peristiwa hari raya Idul Fitri tahun 2019 cukup untuk menggerakkan investor dalam pengambilan keputusan investasinya. Investor dalam melakukan pertimbangan investasi tidak hanya memperhitungkan teknik analisis fundamental seperti melihat kinerja perusahaan, tetapi juga mempertimbangkan peristiwa disekitarnya, seperti peristiwa ekonomi dan nonekonomi untuk memperoleh return dan terhindar dari risiko kerugian investasi.

Hasil penelitian ini didukung oleh penelitian yang dilakukan Hasanuddin (2015) menyatakan bahwa terdapat perbedaan Abnormal Return sebelum dan sesudah peristiwa hari raya Idul Fitri pada saham-saham yang terdaftar di JII maupun non-JII periode 2009-2013. Hal ini sejalan dengan penelitian yang dilakukan oleh Pujiadi \& Indriani (2017) yang menunjukkan terdapat perbedaan Abnormal Return sebelum dan sesudah hari libur Idul Fitri.

Investor dalam penelitian ini bereaksi cepat dalam menyerap informasi sehingga sesuai dengan pasar efisien bentuk setengah kuat. Reaksi pasar akan dicerminkan dengan adanya Abnormal Return yang signifikan. Hal ini sesuai dengan teori kandungan informasi yang menyatakan bahwa apabila suatu peristiwa mengandung informasi maka diharapkan pasar akan bereaksi terhadap peristiwa yang dicerminkan dengan adanya Abnormal Return.

Penelitian dengan menggunakan event study pada peristiwa hari raya Idul Fitri tahun 2019 menunjukkan bahwa peristiwa ini memiliki kandungan informasi yang menyebabkan pelaku pasar bereaksi terhadap peristiwa tersebut. Hasil pengujian menunjukkan terdapat reaksi pasar pada hari raya Idul Fitri tahun 2019 yang ditunjukkan dengan adanya Trading Volume Activity yang signifikan. Hasil ini sesuai dengan hipotesis $2\left(\mathrm{H}_{2}\right)$.

Hasil pengujian hipotesis kedua $\left(\mathrm{H}_{2}\right)$ melalui uji One Sample T-test memperlihatkan bahwa pada tingkat kepercayaan 95\% nilai Sig. (2-tailed) 0,000< 0,05, maka dapat dikatakan bahwa $\mathrm{H}_{2}$ diterima. Hal ini mengartikan bahwa terdapat reaksi pasar atas hari raya Idul Fitri tahun 2019 yang ditunjukkan 
dengan adanya Trading Volume Activity yang signifikan. Peristiwa ini kemungkinan dapat mempengaruhi minat investor untuk melakukan transaksi.

Hasil penelitian ini didukung oleh penelitian yang dilakukan (Setiasri \& Rinofah, 2017) menemukan hasil trading volume activity berpengaruh signifikan pada saat sebelum dan sesudah hari raya Idul Fitri. Hal ini sejalan dengan penelitian yang dilakukan oleh Suhadak \& Hidayat (2016), Utomo \& Herlambang (2015) mendapatkan hasil terdapat perbedaan trading volume activity di bulan Ramadhan. Hasil penelitian ini mendukung teori efisiensi pasar dimana pasar merespon informasi-informasi yang masuk, dan bagaimana informasi tersebut selanjutnya bias mempengaruhi pergerakkan harga sekuritas menuju harga keseimbangan yang baru.

Hasil penelitian ini secara teoritis dapat memberikan bukti empiris yang menguatkan konsep kandungan informasi yang mengatakan apabila suatu peristiwa mengandung informasi, maka diharapkan pasar akan bereaksi terhadap peristiwa yang dicerminkan dengan adanya abnormal return. Sebaliknya peristiwa yang tidak memiliki kandungan informasi tidak memberikan abnormal return kepada pasar serta menguatkan konsep efisiensi pasar yang mengatakan pasar bereaksi dengan cepat dan akurat untuk mencapai harga keseimbangan yang baru yang sepenuhnya dicerminkan oleh informasi yang tersedia sehingga dapat memberikan pengaruh pada reaksi pasar modal. Penelitian ini memberikan tambahan informasi secara empiris mengenai bagaimana reaksi pasar terhadap hari raya Idul Fitri tahun 2019 yang ditunjukkan dengan adanya Abnormal Return dan Trading Volume Activity yang signifikan disekitar peristiwa.

Hasil penelitian ini secara praktis dapat menjadi pertimbangan bagi investor untuk lebih berhati-hati dengan peristiwa ekonomi maupun non ekonomi. Setiap informasi yang diterima oleh pelaku pasar diharapkan dianalisis terlebih dahulu berdasarkan pertimbangan dan karakteristik masingmasing investor, sehingga pelaku pasar modal dapat mengambil keputusan investasi agar mendapatkan pengembalian yang maksimal. Hasil penelitian ini dapat memberikan gambaran mengenai bagaimana pelaku pasar bertindak pada saat peristiwa non-ekonomi hari raya Idul Fitri tahun 2019.

\section{SIMPULAN}

Berdasarkan hasil pengujian hipotesis 1, terdapat reaksi pasar pada saat hari raya Idul Fitri tahun 2019 yang ditunjukkan dengan adanya Abnormal Return disekitar tanggal peristiwa. Hal ini membuktikan bahwa hari raya Idul Fitri mengandung informasi yang mempengaruhi keputusan investor dalam berinvestasi di pasar modal. Berdasarkan hasil pengujian hipotesis 2, terdapat reaksi pasar atas hari raya Idul Fitri tahun 2019 yang ditunjukkan dengan adanya Trading Volume Activity yang signifikan disekitar tanggal peristiwa. pasar modal nampak normal dan tidak menunjukkan perbedaan yang signifikan di sekitar event period. Dalam penelitian ini, pasar merespon informasi-informasi yang masuk sehingga peristiwa ini dapat mempengaruhi minat investor untuk melakukan transaksi.

Penelitian ini dapat menjadi masukan atau pertimbangan sebelum melakukan investasi di pasar modal berdasarkan peristiwa yang terjadi khususnya terkait peristiwa hari raya Idul Fitri. Bagi peneliti selanjutnya 
diharapkan bisa menggunakan peristiwa ekonomi maupun non ekonomi lainnya untuk menguji kandungan informasi dan menjelaskan reaksi pasar pada peristiwa tersebut.

\section{REFERENSI}

Andri, Y. (2013). Reaksi Pasar Modal di Bursa Efek Indonesia Terhadap Pengumuman Peristiwa Bencana Banjir Yang Melanda Daerah Khusus Ibu Kota Jakarta Tahun 2013. Jurnal Nominal, II(II), 135-150.

Anggraini, F. (2017). Analisis Reaksi Pasar Atas Peristiwa Pengumuman Kebijakan Holding BUMN Pertambangan. Skripsi. https://doi.org/10.1017/CBO9781107415324.004

Chang, C. Y., Zhang, Y., Teng, Z., Bozanic, Z., \& Ke, B. (2016). Measuring The Information Content of Financial News. COLING 2016 - 26th International Conference on Computational Linguistics, Proceedings of COLING 2016: Technical Papers, 3216-3225.

Chrisnanti, F. (2015). Perbedaan Nilai Actual Return, Expected Return, Abnormal Return, Trading Volume Activity Dan Security Return Variability Sebelum Dan Sesudah Merjer Pada Perusahaan Yang Terdaftar. Jurnal Bisnis Dan Akuntansi, 17(1), 1-9.

Fama, E. (1970). Efficient Capital Markets: A Review of Theory and Empirical Work. The Journal of Finance, 383-417.

Frankel, R., \& Lee, C. M. C. (1998). Accounting Valuation, Market Expectation, and Cross-Sectional Stock Returns. Journal of Accounting and Economics, 25(3), 283-319. https://doi.org/10.1016/S0165-4101(98)00026-3

Hall, S. G., \& Kenjegaliev, A. (2017). The effect of Oil Price Changes on The Price of Russian and Chinese Oil Shares. Empirical Economics, 1639-1656. https://doi.org/10.1007/s00181-016-1176-3

Hartono, J. (2015). Teori Portofolio dan Analisis Investasi (Kesembilan). Yogyakarta: BPFE.

Harvey, C. R., Liu, Y., \& Zhu, H. (2016). ‥ and the Cross-Section of Expected Returns. Review of Financial Studies, 29(1), 5-68. https://doi.org/10.1093/rfs/hhv059

Hasanuddin. (2015). Analisis Komparatif Abnormal Return Saham JII dan Non JII sebelum dan sesudah Libur Idul Fitri (Periode 2009-2013). Jurnal MIX : (Jurnal Ilmiah Manajemen), VI(2), 246-259.

Jatmiko, D. P., Manahov, V., \& Obiosa, N. (2014). Does Capital Market Reaction to non-Economic Factors Generate Abnormal Returns? Investment Management and Financial Innovations, 11(4), 66-76.

Levine, R., \& Zervos, S. (1998). Stock Markets, Banks, and Economic Growth. American Economic Review, 88(3), 537-558. https://doi.org/10.2307/116848

Marini, E. (2016). Analisis Fenomena Hari Raya Idul Fitri Terhadap Return Saham dan Trading Volume Activity (Studi pada Saham Sub Sektor Food and Beverage di Bursa Efek Indonesia Tahun 2011-2015). Skripsi.

Meylita, H., \& Yasa, G. W. (2015). Perbedaan Reaksi Pasar Atas Pengumuman Pemecahan Saham Pada Lq45 Dan Non Lq45. Jurnal Ilmiah Akuntansi Dan Bisnis, 10(2), 96-104.

Nguyen, H. (2017). CEO Ability and Firm Performance: Stock Market and Job Market 
Reactions. 0-30.

Permana, H. T., Sutejo, B. S., \& Si, M. (2013). Perbedaan Abnormal Return Pada Sektor Keuangan Sebelum dan Sesudah Peristiwa Pilkada Gubernur DKI Jakarta 20 September 2012. Jurnal Ilmiah Universitas Surabaya, 2(1), 1-9. https://doi.org/10.1007/springerreference_639

Pujiadi, B. W., \& Indriani, A. (2017). Analisis Pengaruh Hari Libur Islam terhadap Abnormal Return Saham. Diponegoro Journal of Management, 6(4), $1-12$.

Schatzberg, J. D., \& Datta, P. (1992). The Weekend Effect and Corporate Dividend Announcements. 1992, XV(1), 69-76.

Setiasri, R., \& Rinofah, R. (2017). Pengaruh Ramadhan Terhadap Return dan Volume Perdagangan Saham pada Jakarta Islamic Index (JII). Jurnal Manajemen, 7(1), 57-64.

Suhadak, \& Hidayat, R. R. (2016). Pengaruh Pengumuman Stock Split Terhadap Likuiditas Saham dan Return Saham (Studi pada Perusahaan yang Terdaftar di Bursa Efek Indonesia Periode 2012-2014). Jurnal Administrasi Bisnis (JAB), 38(2), 156-162.

Suryawijaya, M. A., \& Setiawan, F. A. (1998). Reaksi Pasar Modal Indonesia terhadap Peristiwa Politik Dalam Negeri (Event Study pada Peristiwa 27 Juli 1996). KELOLA Gadjah Mada University Business Review, Vol. 7, pp. 137153.

Sutrisno, W., Yuniartha, F., \& Susilowati, S. (2000). Pengaruh Stock Split Terhadap Likuiditas Dan Return Saham Di Bursa Efek Jakarta. Jurnal Manajemen Dan Kewirausahaan, 2(2), 1-13. https://doi.org/10.9744/jmk.2.2.pp.1-13

Umam, M. R. K. (2012). Analisis Kemampuan Rasio Leverage dan Informasi Arus Kas Dalam Memprediksi Laba Perusahaan Yang Akan Datang (Studi pada Perusahaan Go Public yang Terdaftar dalam Jakarta Islamic Index di BEI Periode 2008-2010). Tesis.

Utomo, V. J., \& Herlambang, L. (2015). Efek Hari Libur Lebaran Pada Emiten Yang Terdaftar Dalam Issi Periode 2011-2013. JESTT, 2(5), 372-386. https://doi.org/10.1017/CBO9781107415324.004 